\title{
Do Code of Points in men artistic gymnastics and women artistic gymnastics favor asymmetric elements?
}

CDD. 20.ed. 796.024

796.41

Ivan ČUK*

*Faculty of Sport, University of Ljubljana,

http://dx.doi.org/10.1590/1807-55092016000100009

\begin{abstract}
The purpose of research was to determine whether Code of Point (COP) in Men Artistic Gymnastics (MAG) and Women Artistic Gymnastics (WAG) favor asymmetric elements in order to build gymnast's competition exercise. All elements which are described in MAG $(N=993)$ and WAG $(N=713)$ COP were included and defined if they are symmetric at start position, during movement and at final position. Element is symmetric by arms and trunk with legs activity when all left and right body side performs simultaneously same activity. Results show in MAG COP as a whole is significantly more asymmetric elements with asymmetric trunk and legs activity. In WAG COP as a whole is significantly more asymmetric elements with asymmetric activity of arms, trunk and legs. Hypothetical most difficulty exercises on each apparatus revealed that in general for all around gymnast proportion between asymmetric and symmetric elements is close to $70 \%$ to $30 \%$, what suggests that difficulty relates to increased asymmetry. COP in MAG and WAG enforces asymmetric movements for achieving high results, however, coaches' task is to be aware of COP influence on gymnasts' health and minimize asymmetries in load and to work on symmetric conditioning.
\end{abstract}

KeY WoRDs: Health; Injuries; Symmetric; Activity.

\section{Introduction}

In old booklet from 1919 titled Sokol Principles ${ }^{1}$, under chapter VI. Sokol and Sport write: Sokol movement thinks that for nation education are not suitable sports, which have aim to entertain and expose more than to support physical education. Such sports are hunting, fishing, high performance alpine climbing, horse races, tennis and similar. Sokol will not take any negative actions against those sports, but will not include them into their program. Same position will be to those sports, which promote one side development of human body like cycling and football. However, Sokol understand important influence of some sports, plays and activities in nature for harmonic development of healthy body and mind mostly for young and accepts them into program with modern views about youngsters' hygiene into work plan. Such sports are bathing, swimming, rowing, and ice skating, skiing, hiking without climbing, forest games, and excursion and similar. Youngsters should have physical education under above guideline. In addition, adult members should do same, and Sokol physical education should adopt activities according to age, gender, social class and other particularities of other parts of nation. Neither artistic gymnastics, nor any other sport is compulsory for Sokol members. Nevertheless, all members have to do at least one physical activity, which is in Sokol plan, according to his needs and interests. For all Sokol members are compulsory exercises in row and column (authors remark: exercises which are important for public displays) and calisthenics (authors remark: gymnastic exercises for flexibility and strength). Sokol movement (as one direction of gymnastics movement in Slavic countries) have opinion symmetric exercises are important for human health.

Symmetry is state of being symmetrical; definition of symmetrical: if something is symmetrical, it has two halves which are exactly the same, except that one half is the mirror image of the other ${ }^{2}$.

During history, artistic gymnastics compulsory and optional exercises were long competition tradition. In some cases, there were requested movement on both sides and directions, e.g. pommel horse compulsory exercise included circles in left and right direction ${ }^{3}$. Today Code of Points (COP) in Men 
Artistic Gymnastics (MAG) ${ }^{4}$ and Women Artistic Gymnastics (WAG) ${ }^{5}$ have no words on symmetries, but MAG COP in article 1 paragraph 4 say: the primary purpose of the COP is to guide coaches and gymnasts in the composition of competition exercises; also same text we can find in WAG COP. Without definition of symmetry in COP MAG and WAG do have impact on exercise construction in area of symmetry in ordering element group in exercise and within difficulty, where is important to raise difficulty value of exercise.

On June 30, 2015, Dwight Normile wrote article in International Gymnast Magazine Online with title Rebeca Andrade, Top Prospect for Brazil, Tears ACL, article said she injured only right knee. In the past we were reading many such titles, Correspondence with Dwight Normile (editor of International Gymnast Magazine) revealed we know (perhaps there are more, but not recorded publicly) four cases of simultaneous both limbs injury with elite gymnasts in last 25 years. Dmitri Vasilenko (Russia) broke both ankles in 1992, Igor Korobchinsky (Ukraina) tear both Achilles tendons in 1995, Kyle Shewfelt (Canada) broke both tibias in 2007, and Sam Mikulak (USA) broke both ankles in 2011. In lower level gymnasts, we have less data (and knowledge, as young gymnasts are not in public focus). However, in medicine case reports we found some examples of symmetric injuries. ODA et al. ${ }^{6}$ present a case of bilateral separation of the distal humeral epiphysis of an 11-year-old gymnast; FujIOKA et al. ${ }^{7}$ presented stress fractures of bilateral clavicles in an adolescent gymnast; Syed and O'Flanagan ${ }^{8}$

\section{Method}

Into subjects sample we included all elements from COP in MAG and WAG. If more element variations were in one box, all elements were

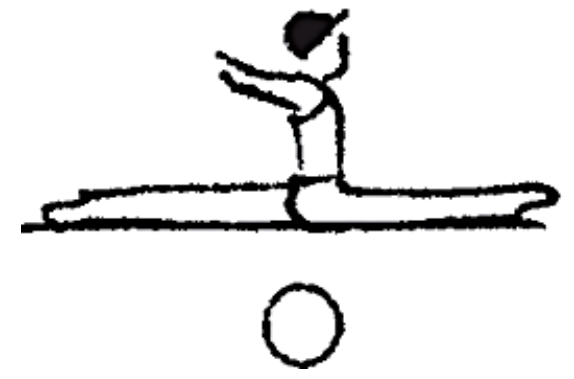

FIGURE 1 - Cross or side split (2s) reported an unusual case of simultaneous bilateral elbow dislocations in female gymnast. Niu et al. ${ }^{9}$ researched biomechanical differences between the non-dominant and dominant limb during landing with legs together; the non-dominant ankle has more effective protective mechanism in excessive joint motion; the dominant ankle joint is at a greater injury risk during drop landing. The greatest dynamic loads on the lower extremities occur for the asymmetrical landings rather than for unsuccessful landings as typically assumed ${ }^{10}$. The asymmetrical, yet reasonably successful landings appear to represent the greatest injury potential for the Achilles tendon, knee joint and spine ${ }^{10}$. A compilation of twenty gymnastics injury rate studies shows a large range of rates being 5.3 to 200 injuries per 100 gymnasts and 0.44 to 22.7 injuries per 1000 hours of participation 11 , what makes elite gymnasts and younger gymnasts a risk population. Within artistic gymnastics, the floor apparatus is associated with the highest injury risk ${ }^{12}$. It is worth to note also asymmetric landing on hands; or exercise on one hand (e.g. round off, pommel horse elements, etc.) could have impact on injury rates of arms. From knowing gymnastics practice and from publicly known data we can assume most injuries are asymmetric (on one body side only).

Aim of research is to determine for each element, in COP for MAG and WAG, whether is symmetrical in arms use and whether is symmetrical in trunk and legs use. Next aim is to determine proportion between symmetric and asymmetric elements on each MAG and WAG apparatus also according to element group membership.

included into sample (FIGURE 1). In MAG COP is 993 elements and in WAG COP 719 elements.

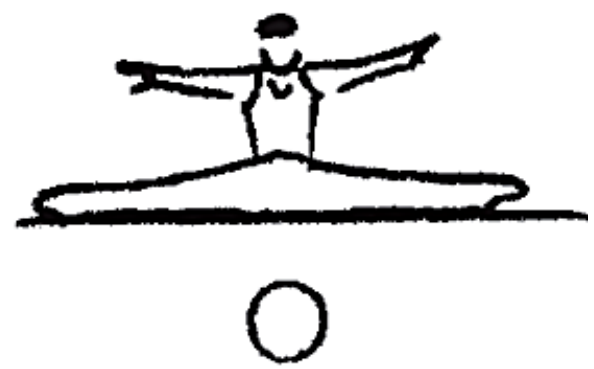


Variables were name of apparatus (Men: floor exercise (MFX), pommel horse (MPH), rings (MRI), vault (MVT), parallel bars (MPB), horizontal bar (MHB); Women: vault WVT, uneven bars (WUB), balance beam (WBB), floor exercise WFX), element group, variable number in COP, and value for symmetric arm activity and value for symmetric trunk and leg activity. Value 0 was for asymmetric activity and value 1 for symmetric activity. Criteria to define something as symmetric: both legs take off, both arms simultaneously same activity, elements without turns; symmetric activity required in start position, during movement and in end position. In case of elements on FIGURE 1 their values are:

Cross split - MFX 16110 (MFX- Men Floor Exercise, 1 - group, 61 - element number, 1 - arms activity, 0 - legs activity)

Side split - MFX 16111 (MFX- Men Floor Exercise, 1 - group, 61 - element number, 1 - arms activity, 1 - legs activity)

All data have analyzed with IBM SPSS Statistics 22, frequencies and Chi Square were calculated. With Chi Square have tested whether number of elements with symmetric/asymmetric are same (50:50); test was significant when higher than 3.841 with $\mathrm{p}<0.05$.

\section{Results}

TABLE 1 - MAG elements symmetry for arms and legs for whole COP, per apparatus and per element group.

\begin{tabular}{|c|c|c|c|c|c|c|}
\hline Variable & $\mathbf{N}$ & Asymmetric (\%) & Symmetric (\%) & Chi square & Sig. & \multirow{25}{*}{$\begin{array}{l}\text { M: men; } \\
\text { FX: floor exercise; } \\
\text { PH: pommel horse; } \\
\text { RI: rings; } \\
\text { VT: vault; } \\
\text { PB: parallel bars; } \\
\text { HB: horizontal bar; } \\
\text { n.s.: not significant. }\end{array}$} \\
\hline MAG arms & 993 & 59.5 & 40.5 & 3.61 & n.s. & \\
\hline MAG legs & 993 & 61.4 & 38.6 & 5.19 & $\mathrm{p}<0.05$ & \\
\hline MFX arms & 196 & 55.1 & 44.9 & 1.04 & n.s. & \\
\hline Group 1 & 75 & 42.7 & 57.3 & 2.13 & n.s. & \\
\hline Group 2 & 48 & 37.5 & 62.5 & 6.25 & $\mathrm{p}<0.05$ & \\
\hline Group 3 & 37 & 59.5 & 40.5 & 3.61 & n.s. & \\
\hline Group 4 & 36 & 100 & 0 & 100.00 & $\mathrm{p}<0.05$ & \\
\hline MFX legs & 196 & 67.3 & 32.7 & 11.97 & $\mathrm{p}<0.05$ & \\
\hline Group 1 & 75 & 57.3 & 42.7 & 2.13 & n.s. & \\
\hline Group 2 & 48 & 58.3 & 41.7 & 2.75 & n.s. & \\
\hline Group 3 & 37 & 67.6 & 32.4 & 12.39 & $\mathrm{p}<0.05$ & \\
\hline Group 4 & 36 & 100 & 0 & 100.00 & $\mathrm{p}<0.05$ & \\
\hline $\mathrm{MPH}$ arms & 133 & 100 & 0 & 100.00 & $\mathrm{p}<0.05$ & \\
\hline Group 1 & 25 & 100 & 0 & 100.00 & $\mathrm{p}<0.05$ & \\
\hline Group 2 & 29 & 100 & 0 & 100.00 & $\mathrm{p}<0.05$ & \\
\hline Group 3 & 30 & 100 & 0 & 100.00 & $\mathrm{p}<0.05$ & \\
\hline Group 4 & 37 & 100 & 0 & 100.00 & $\mathrm{p}<0.05$ & \\
\hline Group 5 & 12 & 100 & 0 & 100.00 & $\mathrm{p}<0.05$ & \\
\hline MPH legs & 133 & 100 & 0 & 100.00 & $\mathrm{p}<0.05$ & \\
\hline Group 1 & 25 & 100 & 0 & 100.00 & $\mathrm{p}<0.05$ & \\
\hline Group 2 & 29 & 100 & 0 & 100.00 & $\mathrm{p}<0.05$ & \\
\hline Group 3 & 30 & 100 & 0 & 100.00 & $\mathrm{p}<0.05$ & \\
\hline Group 4 & 37 & 100 & 0 & 100.00 & $\mathrm{p}<0.05$ & \\
\hline Group 5 & 12 & 100 & 0 & 100.00 & $\mathrm{p}<0.05$ & \\
\hline
\end{tabular}

to be continued 
Čuk I.

TABLE 1 - MAG elements symmetry for arms and legs for whole COP, per apparatus and per element group. (continuation).

M: men;

FX: floor exercise;

$\mathrm{PH}$ : pommel horse;

$\mathrm{Rl}$ : rings;

VT: vault;

PB: parallel bars;

$\mathrm{HB}$ : horizontal bar;

n.s.: not significant.

\begin{tabular}{|c|c|c|c|c|c|}
\hline Variable & $\mathbf{N}$ & Asymmetric (\%) & Symmetric (\%) & Chi square & Sig. \\
\hline MRI arms & 176 & 15.9 & 84.1 & 46.51 & $\mathrm{p}<0.05$ \\
\hline Group 1 & 40 & 0 & 100 & 100.00 & $\mathrm{p}<0.05$ \\
\hline Group 2 & 6 & 0 & 100 & 100.00 & $\mathrm{p}<0.05$ \\
\hline Group 3 & 31 & 0 & 100 & 100.00 & $\mathrm{p}<0.05$ \\
\hline Group 4 & 60 & 0 & 100 & 100.00 & $\mathrm{p}<0.05$ \\
\hline Group 5 & 39 & 71.8 & 28.2 & 19.00 & $\mathrm{p}<0.05$ \\
\hline MRI legs & 176 & 15.9 & 84.1 & 46.51 & $\mathrm{p}<0.05$ \\
\hline Group 1 & 40 & 0 & 100 & 100.00 & $\mathrm{p}<0.05$ \\
\hline Group 2 & 6 & 0 & 100 & 100.00 & $\mathrm{p}<0.05$ \\
\hline Group 3 & 31 & 0 & 100 & 100.00 & $\mathrm{p}<0.05$ \\
\hline Group 4 & 60 & 0 & 100 & 100.00 & $\mathrm{p}<0.05$ \\
\hline Group 5 & 39 & 71.8 & 28.2 & 19.00 & $\mathrm{p}<0.05$ \\
\hline MVT arms & 104 & 94.2 & 5.8 & 78.14 & $\mathrm{p}<0.05$ \\
\hline Group 1 & 33 & 81.8 & 18.2 & 40.44 & $\mathrm{p}<0.05$ \\
\hline Group 2 & 23 & 100 & 0 & 100.00 & $\mathrm{p}<0.05$ \\
\hline Group 3 & 18 & 100 & 0 & 100.00 & $\mathrm{p}<0.05$ \\
\hline Group 4 & 16 & 100 & 0 & 100.00 & $\mathrm{p}<0.05$ \\
\hline Group 5 & 14 & 100 & 0 & 100.00 & $\mathrm{p}<0.05$ \\
\hline MVT legs & 104 & 94.2 & 5.8 & 78.14 & $\mathrm{p}<0.05$ \\
\hline Group 1 & 33 & 81.8 & 18.2 & 40.44 & $\mathrm{p}<0.05$ \\
\hline Group 2 & 23 & 100 & 0 & 100.00 & $\mathrm{p}<0.05$ \\
\hline Group 3 & 18 & 100 & 0 & 100.00 & $\mathrm{p}<0.05$ \\
\hline Group 4 & 16 & 100 & 0 & 100.00 & $\mathrm{p}<0.05$ \\
\hline Group 5 & 14 & 100 & 0 & 100.00 & $\mathrm{p}<0.05$ \\
\hline $\mathrm{MPB}$ arms & 186 & 58.1 & 41.9 & 2.62 & n.s. \\
\hline Group 1 & 65 & 66.2 & 33.8 & 10.49 & $\mathrm{p}<0.05$ \\
\hline Group 2 & 28 & 53.6 & 46.4 & 0.51 & n.s. \\
\hline Group 3 & 37 & 45.9 & 54.1 & 0.67 & n.s. \\
\hline Group 4 & 33 & 45.9 & 54.5 & 0.74 & n.s. \\
\hline Group 5 & 23 & 78.3 & 21.7 & 32.03 & $\mathrm{p}<0.05$ \\
\hline MPB legs & 186 & 56.5 & 43.5 & 1.69 & n.s. \\
\hline Group 1 & 65 & 64.6 & 35.4 & 8.52 & $\mathrm{p}<0.05$ \\
\hline Group 2 & 28 & 53.6 & 46.4 & 0.51 & n.s. \\
\hline Group 3 & 37 & 40.5 & 59.5 & 3.61 & n.s. \\
\hline Group 4 & 33 & 45.5 & 54.5 & 0.81 & n.s. \\
\hline Group 5 & 23 & 78.3 & 21.7 & 32.03 & $\mathrm{p}<0.05$ \\
\hline
\end{tabular}

to be continued

12 • Rev Bras Educ Fís Esporte, (São Paulo) 2016 Jan-Mar; 3o(1):9-18 
TABLE 1 - MAG elements symmetry for arms and legs for whole COP, per apparatus and per element group. (continuation).

\begin{tabular}{rccccc}
\hline Variable & $\mathbf{N}$ & Asymmetric (\%) & Symmetric (\%) & Chi square & Sig. \\
\hline MHB arms & 198 & 61.6 & 38.4 & 5.38 & $\mathrm{p}<0.05$ \\
Group 1 & 27 & 77.8 & 22.2 & 30.91 & $\mathrm{p}<0.05$ \\
Group 2 & 58 & 51.7 & 48.3 & 0.11 & n.s. \\
Group 3 & 34 & 64.7 & 35.3 & 8.64 & $\mathrm{p}<0.05$ \\
Group 4 & 22 & 45.5 & 54.5 & 0.81 & n.s. \\
Group 5 & 57 & 68.4 & 31.6 & 13.54 & $\mathrm{p}<0.05$ \\
MHB legs & 198 & 60.6 & 39.4 & 4.49 & $\mathrm{p}<0.05$ \\
Group 1 & 27 & 70.4 & 39.6 & 10.48 & $\mathrm{p}<0.05$ \\
Group 2 & 58 & 51.7 & 48.3 & 0.11 & n.s. \\
Group 3 & 34 & 64.7 & 35.3 & 8.64 & $\mathrm{p}<0.05$ \\
Group 4 & 22 & 45.5 & 54.5 & 0.81 & n.s. \\
Group 5 & 57 & 68.4 & 31.6 & 13.54 & $\mathrm{p}<0.05$ \\
\hline
\end{tabular}

M: men;

FX: floor exercise; $\mathrm{PH}$ : pommel horse; Rl: rings;

VT: vault;

PB: parallel bars;

HB: horizontal bar;

n.s.: not significant.

TABLE 2 - WAG elements symmetry for arms and legs for whole COP, per apparatus and per element group.

\begin{tabular}{|c|c|c|c|c|c|c|}
\hline Variable & $\mathbf{N}$ & Asymmetric (\%) & Symmetric (\%) & Chi square & Sig. & \multirow{15}{*}{$\begin{array}{l}\text { W: women; } \\
\text { VT: vault; } \\
\text { UB: uneven bars; } \\
\text { BB: balance beam; } \\
\text { FX: floor exercise; } \\
\text { n.s.: not significant }\end{array}$} \\
\hline WAG arms & 719 & 64.8 & 35.2 & 8.76 & $\mathrm{p}<0.05$ & \\
\hline WAG legs & 719 & 74.1 & 25.9 & 23.23 & $\mathrm{p}<0.05$ & \\
\hline WVT arms & 79 & 92.4 & 7.6 & 71.91 & $\mathrm{p}<0.05$ & \\
\hline Group 1 & 21 & 90.5 & 9.5 & 65.61 & $\mathrm{p}<0.05$ & \\
\hline Group 2 & 15 & 73.3 & 26.7 & 21.71 & $\mathrm{p}<0.05$ & \\
\hline Group 3 & 12 & 100 & 0 & 100.00 & $\mathrm{p}<0.05$ & \\
\hline Group 4 & 19 & 100 & 0 & 100.00 & $\mathrm{p}<0.05$ & \\
\hline Group 5 & 12 & 100 & 0 & 100.00 & $\mathrm{p}<0.05$ & \\
\hline WVT legs & 79 & 92.4 & 7.6 & 71.91 & $\mathrm{p}<0.05$ & \\
\hline Group 1 & 21 & 90.5 & 9.5 & 65.61 & $\mathrm{p}<0.05$ & \\
\hline Group 2 & 15 & 73.3 & 26.7 & 21.71 & $\mathrm{p}<0.05$ & \\
\hline Group 3 & 12 & 100 & 0 & 100.00 & $\mathrm{p}<0.05$ & \\
\hline Group 4 & 19 & 100 & 0 & 100.00 & $\mathrm{p}<0.05$ & \\
\hline Group 5 & 12 & 100 & 0 & 100.00 & $\mathrm{p}<0.05$ & \\
\hline
\end{tabular}

to be continued 
Čuk I.

W: women;

VT: vault;

UB: uneven bars:

BB: balance beam;

FX: floor exercise;

n.s.: not significant.

TABLE 2 - WAG elements symmetry for arms and legs for whole COP, per apparatus and per element group. (continuation).

\begin{tabular}{|c|c|c|c|c|c|}
\hline Variable & $\mathbf{N}$ & Asymmetric (\%) & Symmetric (\%) & Chi square & Sig. \\
\hline WUB arms & 239 & 52.7 & 47.3 & 0.29 & n.s. \\
\hline Group 1 & 36 & 52.8 & 47.2 & 0.31 & n.s. \\
\hline Group 2 & 26 & 46.2 & 53.8 & 0.57 & n.s. \\
\hline Group 3 & 40 & 67.5 & 32.5 & 12.25 & $\mathrm{p}<0.05$ \\
\hline Group 4 & 36 & 38.9 & 61.1 & 4.92 & $\mathrm{p}<0.05$ \\
\hline Group 5 & 41 & 31.7 & 68.3 & 13.39 & $\mathrm{p}<0.05$ \\
\hline Group 6 & 60 & 68.3 & 31.7 & 13.39 & $\mathrm{p}<0.05$ \\
\hline WUB legs & 239 & 52.3 & 47.7 & 0.21 & n.s. \\
\hline Group 1 & 36 & 52.8 & 47.2 & 0.31 & n.s. \\
\hline Group 2 & 26 & 46.2 & 53.8 & 0.57 & n.s. \\
\hline Group 3 & 40 & 67.5 & 32.5 & 12.25 & $\mathrm{p}<0.05$ \\
\hline Group 4 & 36 & 38.9 & 61.1 & 4.92 & $\mathrm{p}<0.05$ \\
\hline Group 5 & 41 & 29.3 & 70.7 & 17.13 & $\mathrm{p}<0.05$ \\
\hline Group 6 & 60 & 68.3 & 31.7 & 13.39 & $\mathrm{p}<0.05$ \\
\hline WBB arms & 261 & 62.8 & 37.2 & 6.55 & $\mathrm{p}<0.05$ \\
\hline Group 1 & 74 & 59.5 & 40.5 & 3.61 & n.s. \\
\hline Group 2 & 48 & 60.4 & 39.6 & 4.32 & $\mathrm{p}<0.05$ \\
\hline Group 3 & 26 & 100 & 0 & 100.00 & $\mathrm{p}<0.05$ \\
\hline Group 4 & 30 & 46.7 & 53.3 & 0.43 & n.s. \\
\hline Group 5 & 46 & 52.2 & 47.8 & 0.19 & n.s. \\
\hline Group 6 & 37 & 73.0 & 27 & 21.16 & $\mathrm{p}<0.05$ \\
\hline WBB legs & 261 & 82.0 & 18.0 & 40.96 & $\mathrm{p}<0.05$ \\
\hline Group 1 & 74 & 74.3 & 25.7 & 23.61 & $\mathrm{p}<0.05$ \\
\hline Group 2 & 48 & 83.3 & 16.7 & 44.35 & $\mathrm{p}<0.05$ \\
\hline Group 3 & 26 & 100 & 0 & 100.00 & $\mathrm{p}<0.05$ \\
\hline Group 4 & 30 & 86.7 & 13.3 & 53.87 & $\mathrm{p}<0.05$ \\
\hline Group 5 & 46 & 78.3 & 21.7 & 32.03 & $\mathrm{p}<0.05$ \\
\hline Group 6 & 37 & 83.8 & 16.2 & 45.69 & $p<0.05$ \\
\hline WFX arms & 140 & 73.6 & 26.4 & 22.27 & $\mathrm{p}<0.05$ \\
\hline Group 1 & 59 & 69.5 & 30.5 & 15.21 & $\mathrm{p}<0.05$ \\
\hline Group 2 & 18 & 100 & 0 & 100.00 & $\mathrm{p}<0.05$ \\
\hline Group 3 & 18 & 66.7 & 33.3 & 11.15 & $\mathrm{p}<0.05$ \\
\hline Group 4 & 24 & 75.0 & 25.0 & 25.00 & $\mathrm{p}<0.05$ \\
\hline Group 5 & 21 & 66.7 & 33.3 & 11.15 & $\mathrm{p}<0.05$ \\
\hline WFX legs & 140 & 86.4 & 13.6 & 52.99 & $\mathrm{p}<0.05$ \\
\hline Group 1 & 59 & 91.5 & 8.5 & 68.89 & $\mathrm{p}<0.05$ \\
\hline Group 2 & 18 & 100 & 0 & 100.00 & $\mathrm{p}<0.05$ \\
\hline Group 3 & 18 & 72.2 & 27.8 & 19.71 & $\mathrm{p}<0.05$ \\
\hline Group 4 & 24 & 83.3 & 16.7 & 44.35 & $\mathrm{p}<0.05$ \\
\hline Group 5 & 21 & 76.2 & 23.6 & 27.66 & $\mathrm{p}<0.05$ \\
\hline
\end{tabular}

14 - Rev Bras Educ Fís Esporte, (São Paulo) 2016 Jan-Mar; 30(1):9-18 


\section{Discussion}

In general, in MAG COP is number of elements with symmetric arms activity similar with those asymmetric ones. However, in case of trunk and legs activity there is significantly more asymmetric elements than symmetric ones. On floor proportion of symmetric and asymmetric elements are similar. Elements are divided into four groups, two of them (group two - acrobatic jumps forward; and group four - acrobatic jumps sideward or with $1 / 2$ turn and salto backward or sideward) have significantly higher number of asymmetric elements in arms activity. In case of trunk and legs activity there is significantly more elements with asymmetry, most of them in group three (acrobatic jumps backwards) and four (acrobatic jumps sideward or with $1 / 2$ turn and salto backward or sideward). On pommel horse, all activity is asymmetric either for arms for both trunk and legs. Most opposite to pommel horse are rings, where all activity is in theory symmetric, except in-group five (dismounts) we can find more asymmetric dismounts than symmetric ones. On vault is more asymmetric vaults, than symmetric ones, only group 1 with handspring forward includes symmetric jumps, both for arms and for trunk and legs activity. Parallel bars have almost equal number of symmetric and asymmetric elements for arms and trunk and legs activity. In two group asymmetric elements prevail, in-group one (elements in support or through support) and five (dismounts). On high bar, asymmetric elements prevail in general for arms and trunk and legs activity. Only in two group in-group two (flight elements) and group four (elements near the bar) there are equal numbers of symmetric and asymmetric elements.

TABLE 3 - Hypothetic most difficult exercise on men apparatus, with respect to all COP rules and with maximizing number of symmetric elements.

\begin{tabular}{|c|c|c|c|c|c|c|c|}
\hline Element & MFX & MPH & MRI & MVT & MPB & MHB & \multirow{12}{*}{$\begin{array}{l}\text { In cell per apparatus is } \\
\text { first element group in } \\
\text { roman numbers, than } \\
\text { element number in MAG } \\
\text { COP, difficulty, letter A } \\
\text { for asymmetric element } \\
\text { and } S \text { for symmetric } \\
\text { one. }\end{array}$} \\
\hline 1 & III,36,F,A & $\mathrm{I}, 4, \mathrm{D}, \mathrm{A}$ & IV,48,F,S & $\mathrm{I}, 48,6.4, \mathrm{~A}$ & $\mathrm{I}, 30, \mathrm{~F}, \mathrm{~A}$ & II,66,G,A & \\
\hline 2 & IV,12,F,A & II, 54, G,A & IV,72,F,S & II,38,6.4,A & II,12,G,A & II,78,G,A & \\
\hline 3 & III,24,F,A & IV,65+2flops, G,A & IV,60,F,S & & II,18,F,A & II,96,G,A & \\
\hline 4 & IV,24,F,A & IV,47,E,A & III,6,F,S & & II,24,F,S & II,90,F,A & \\
\hline 5 & II,48,F,A & IV,65,E,A & III,28,D,S & & III,36,G,A & IV,5,E,A & \\
\hline 6 & $\mathrm{I}, 10, \mathrm{D}, \mathrm{S}$ & III,47,E,A & I,29,E,S & & III,48,F,A & III,41,E,A & \\
\hline 7 & II,29,E,S & III,29,E,A & I, 35,E,S & & $\mathrm{IV}, 12, \mathrm{G}, \mathrm{A}$ & I,64,D,A & \\
\hline 8 & II,59,E,A & II,30,F, A & $\mathrm{I}, 52, \mathrm{D}, \mathrm{S}$ & & IV,18,F,A & $\mathrm{IV}, 10, \mathrm{D}, \mathrm{S}$ & \\
\hline 9 & III,6,G,A & $\mathrm{II}, 29, \mathrm{D}, \mathrm{A}$ & II,16,D,S & & III,5,E,S & $\mathrm{IV}, 28, \mathrm{D}, \mathrm{S}$ & \\
\hline 10 & III,12,G,S & $\mathrm{V}, 5, \mathrm{E}, \mathrm{A}$ & V,36,F,S & & V,30,G,A & $\mathrm{V}, 6, \mathrm{~F}, \mathrm{~S}$ & \\
\hline Proportion A/S & $7 / 3$ & $10 / 0$ & $0 / 10$ & $2 / 0$ & $9 / 1$ & $7 / 3$ & \\
\hline
\end{tabular}

As can be noted from TABLE 3, a super gymnast who could perform all the most difficult elements would have only on rings elements, which support symmetry. On other apparatus, asymmetry is dominant, on pommel horse and vault it is $100 \%$. In general, proportion is $70 \%: 30 \%$. Comparing to results in TABLE 1 asymmetry in TABLE 2 is higher. It mostly seems difficulty raises on more asymmetry. ČuK at al. ${ }^{13}$ found significant differences in morphologic characteristics between left and right arm in elbow diameter, circumference of forearm, skinfold thickness of triceps brachia and skinfold thickness of triceps brachia. While they did not found any significant morphologic adaptation to asymmetric loads in legs; they presumed mostly load on pommel horse and parallel bars had impact on arms, with COP analyze we can confirm their thesis and add that probably also all other apparatus except rings have also impact on it.

In general, in WAG COP number of elements with symmetric arms activity and asymmetric ones is significantly higher number of asymmetric ones. Ratio is in average close to $70 \%$ to $30 \%$, what is slightly more than in MAG general, and close to what is in MAG most difficulty exercises. On vault are mostly only asymmetric jumps, only few of them 
Čuk I.

are in the first and second group where handsprings forward with salto without turns are. Uneven bars are the most balanced apparatus, according to number symmetric and asymmetric elements with arms, and trunk and leg activity. It is worth to note, in-group four (Stalder circles) and five (pike circles) there is much more symmetric elements than asymmetric, while in-group three (giant circles) is just opposite.
On balance beam, elements with asymmetry prevail in arms activity slightly, and in trunk and legs activity severely. Trunk and legs asymmetry is significantly higher in all groups, while for arms activity only in groups two (gymnastics leaps, jumps and hops), three (gymnastics turns) and six (dismounts). On floor exercise in general and in all group, significantly prevail asymmetric elements in number.

TABLE 4 - Hypothetic most difficult exercise on women apparatus, with respect to all COP rules and with maximizing number of symmetric elements.

In cell per apparatus is first element group in roman numbers, than element number in WAG COP, difficulty, letter A for asymmetric element and $\mathrm{S}$ for symmetric one.

\begin{tabular}{lcccc}
\hline Element & WVT & WUB & WBB & WFX \\
\hline 1 & II,50,7.0,S & III,705,G,A & V,613,F,A & I,404,D,A \\
2 & III,35,6.5,A & III,708,G,S & V,713,G,A & I,405,D,A \\
3 & & II,505,E,A & V,611,F,A & II,501,E,A \\
4 & & III,502,E,A & V.412,D,A & IV,705,G,A \\
5 & & III,506,E,A & III,507,E,A & IV,601,F,A \\
6 & & IV,602,F,S & II,502,E,A & V,802,H,A \\
7 & & V,709,G,S & II,512,E,A & V,803,H,A \\
8 & & VI,707,G,S & VI,705,G,A & V,603,F, \\
Proportion A/S & & $4 / 4$ & $8 / 0$ & $7 / 1$ \\
\hline
\end{tabular}

TABLE 4 shows which difficulties could perform a super gymnast in her exercise. On vault and uneven bars hypothetical ratio between asymmetric and symmetric element is 50:50, while on balance beam and floor exercise ratio is completely in favor of asymmetric elements. For those who would compete in all around ratio is $77 \%: 23 \%$ in favor of asymmetric elements and again, like for MAG we can presume difficulty increases asymmetry. DoudA et al. ${ }^{14}$ investigated the influence of long-term training on anthropometric parameters of rhythmic sports and artistic gymnasts and they found significant differences in circumferences between the right and left legs, but surprisingly only in rhythmic gymnasts, not in artistic gymnasts. It is a question if similar results could be get today as WAG COP since 2002 severely changed. BARAKAT et al. ${ }^{15}$ assessed the position of the anterior and posterior iliac spine and gymnasts as a group have asymmetrically positioned innominate bones as opposed to non-gymnasts representing the control group; by repeating asymmetrical physical activities bilateral differences between extremities and bones is expected to enlarge with time.

The main document for MAG and WAG is COP, which determines content of gymnast's exercise and therefore gymnasts' training program. Quite an ordinary are gymnastics injuries of one body part, while there are very rare accidents when both limbs are simultaneously and symmetric injured. Up to now nobody analysed COP for symmetric and asymmetric elements and relate them towards injuries. The first step is to analyze COP and later to relate it to the injuries. For present COP in MAG and WAG we found:

- In MAG COP as a whole is significantly more asymmetric elements with asymmetric trunk and legs activity;

- On pommel horse are all elements asymmetric ones;

- On rings are all elements symmetric, except dismounts, where asymmetric elements prevail;

- On men's vault asymmetric jumps severely prevail;

- On high bar, asymmetric elements slightly prevail;

- On men's floor exercise and parallel bars in are arms activity equal, also this is valid for parallel bars trunk and legs activity, while floor exercise trunk and legs activity promotes asymmetric elements.

- In MAG within element group per each apparatus are in general in favor of asymmetric elements, except on floor in group of acrobatic jumps forward, where are in favor of symmetric ones.

- In WAG COP as a whole is significantly more asymmetric elements with asymmetric activity of arms, trunk and legs. 
- On women vault, floor exercise and balance beam asymmetric element severely prevail in arm, trunk and legs activity.

- On uneven bars, number of symmetric and asymmetric elements are similar.

- In WAG within element group per each apparatus are in general in favor of asymmetric elements, except on uneven bars in-group of Stalder circles and Piked circles.
Hypothetical most difficulty exercises on each apparatus revealed that in general for all around gymnast proportion between asymmetric and symmetric elements is close to $70 \%$ to $30 \%$, what suggests that difficulty relates to increased asymmetry. COP in MAG and WAG enforces asymmetric movements for achieving high results, however, coaches' task is to be aware of COP influence on gymnasts' health and minimize asymmetries in load and to work on symmetric conditioning.

\section{Resumo}

0 Código de Pontuação na ginástica artística feminina e masculina favorecem elementos assimétricos?

A pesquisa investigou se o Código de Pontuação (COP) da Ginástica Artística Masculina (MAG) e da Ginástica Artística Feminina (WAG) favoreciam elementos assimétricos, a fim de arquitetar elementos competitivos do ginasta. Todos os elementos descritos no COP da MAG $(N=993)$ e WAG $(N=713)$ foram analisados em suas posições de início, durante a na posição final no que se refere à simetria. Foram considerados simétricos os movimentos em que braços, troncos e pernas eram ativados simultaneamente e do mesmo lado. Os resultados mostraram que no COP MAG há um número significativamente maior de elementos assimétricos, sobretudo na relação tronco e pernas. No COP WAG há um maior número de elementos assimétricos entre braços, tronco e pernas. Hipoteticamemte, os exercícios com maior dificuldade em cada um dos aparelhos revelaram que a proporção entre elementos assimétricos e simétricos é de cerca de 70\% e $30 \%$ respectivamente, o que releva que a dificuldade está associada com maior assimetria. O COP na MAG e WAG reforçam que realizar movimento assimétricos amplia o grau de dificuldade e elevados resultados, no entanto, os técnicos devem se atentar ao COP e sua influência no bem-estar dos ginastas, minimizando cargas assimetrias e trabalhado em condicionamento simétric.

Palavras-chave: Saúde; Lesões; Simetria; Atividade.

\section{References}

1. Slovenska Sokolska zveza. Sokolska načela [Sokol Principles]. Ljubljana: SSZ; 1919.

2. Sinclair J. Collins Cobuild: English language dictionary. London: Collins ELT; 1989.

3. Štukelj L. Mojih sedem svetovnih tekmovanj [My Seven World Competitions]. Novo Mesto: Dolenjska založba; 1989.

4. Fédération Internationale de Gymnastique. MAG Code of Points 2013-2016. Lausanne: FIG; 2013.

5. Fédération Internationale de Gymnastique. WAG Code of Points 2013-2016. Lausanne: FIG; 2013.

6. Oda R, Fujiwara H, Ichimaru K, Morihara T, Ikeda T, Kubo T. Chronic slipping of bilateral distal humeral epiphyses in a gymnastist. J Ped Orthop. 2015;24:67-70.

7. Fujioka H, Nishikawa T, Koyama S, et al. Stress fractures of bilateral clavicles in an adolescent gymnast. J Shoulder Elb Surg. 2014;23:e88-90.

8. Syed AA, O’Flanagan J. Simultaneous bilateral elbow dislocation in an international gymnast. Br J Sport Med. 1999;33:132-3.

9. Niu W, Wang Y, He Y, Fan Y, Zhao Q. Kinematics, kinetics, and electromyogram of ankle during drop landing: acomparison between dominant and non-dominant limb. Hum Mov Sci. 2011;30:614-23.

10. Panzer VP. Lower extremity loads in landings of elite gymnasts [doctoral dissertation]. Eugene(OR): University of Oregon; 1987. 
Čuk I.

11. Dowdell T. Is gymnastics a dangerous sport in the Australian club context? Sci Gymnastics J. 2011;3:13-25.

12. Kirialanis P, Malliou P, Beneka A, et al. Injuries in artistic gymnastic elite adolescent male and female athletes. J Back Musculoskelet Rehabil. 2002;16:145-51.

13. Čuk I, Bučar Pajek M, Jakše B, Pajek J, Peček M. Morphologic bilateral differences of top level gymnasts. Int J Morphol. 2012:1:110-4.

14. Douda H, Laparidis K, Tokmakidis S. Long-term training induces specific adaptations on the physique of rhythmic sports and female artistic gymnasts. Eur J Sport Sci. 2002;2:1-13.

15. Barakatt E, Smidt GL, Dawson JD, Wei SH, Heiss DG. Interinnominate motion and symmetry: comparison between gymnasts and nongymnasts. J Orthop Sport Phys Ther. 1996;23:309-19.

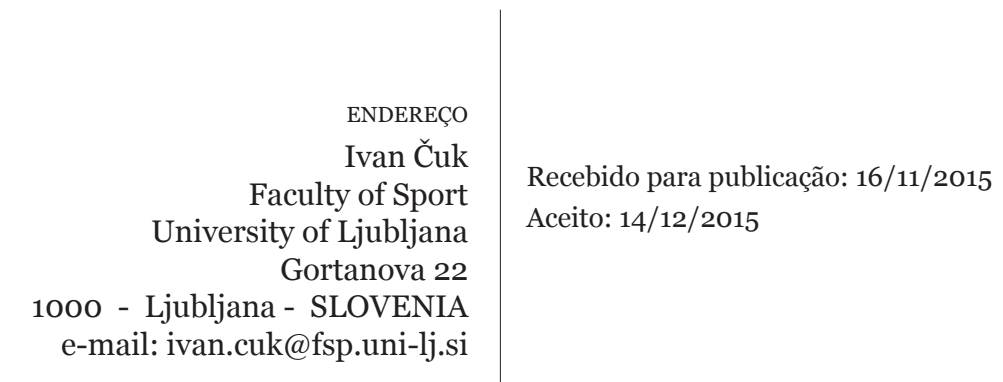

18 • Rev Bras Educ Fís Esporte, (São Paulo) 2016 Jan-Mar; 30(1):9-18 